\title{
Tinjauan Kualitas Air Terhadap Tingkat Kelayakan Teluk Pangandaran Untuk Budidaya Udang Vaname (Litopenaeus vannamei)
}

\author{
Review of Water Quality on The Feasibility of Teluk Pangandaran For Vaname \\ (Litopenaeus vannamei) Cultivation
}

\author{
Yuke Eliyani', lin Siti Djunaidah', Dinno Sudinno² \\ 1Jurusan Penyuluhan Perikanan-Sekolah Tinggi Perikanan \\ Jl. Cikaret No.2 Bogor Selatan Kota Bogor \\ 2 Politeknik Perikanan Pangandaran
}

\begin{abstract}
Abstrak
Penelitian ini bertujuan untuk mengetahui kelayakan teluk Pangandaran untuk budidaya Vaname (Litopenaeus vannamei) ditinjau dari nilai parameter kualitas air. Lokasi penelitian adalah di Kecamatan Cijulang, Cimerak serta Cikangkung Kabupaten Pangandaran Provinsi Jawa Barat. Penelitian ini merupakan penelitian eksplorasi dengan metode survei. Hasil analisis kualitas air untuk parameter suhu, $\mathrm{pH}, \mathrm{TSS}, \mathrm{NO}_{2}, \mathrm{NO}_{3}, \mathrm{DO}, \mathrm{BOD}_{5}$, serta $\mathrm{PO}_{4}-\mathrm{P}$ masing - masing sebesar 24-24,5 ${ }^{\circ} \mathrm{C} ; 7,62-7,90$ ppm; 0,004 - 0,009 ppm; 0,176 - 0,269 ppm; 4,3 - 6,6 ppm; 0,070 $0,980 \mathrm{ppm} ; 0,0122-0,00415 \mathrm{ppm}$. Bedasarkan nilai-nilai parameter tersebut, kualitas air ketiga lokasi penelitian masih layak untuk budidaya Vaname, namun harus disertai dengan tambahan input teknologi pengelolaan kualitas air.
\end{abstract}

Kata Kunci : analisis; budidaya; kelayakan; kualitas air; pengelolaan; Vaname

\section{Abstract}

This study aims to determine the feasibility of Pangandaran bay for the cultivation of Vaname (Litopenaeus vannamei) based on water quality parameter values. This research was conducted in the District of Cijulang, Cimerak, and Cikangkung, located in Pangandaran Regency, West Java Province. This is an exploratory study using the survey method. Water quality analysis result for parameters which are temperature, $\mathrm{pH}, \mathrm{TSS}, \mathrm{NO}_{2}, \mathrm{NO}_{3}, \mathrm{DO}, \mathrm{BOD}_{5}$, and $\mathrm{PO}_{4}-\mathrm{P}$ shows $24-24,5$ ${ }^{\circ} \mathrm{C} ; 7,62-7,90$ ppm; 0,004-0,009 ppm; 0,176-0,269 ppm; 4,3-6,6 ppm; 0,070-0,980 ppm; $0,0122-0,00415 \mathrm{ppm}$. Based on these parameters value, the water quality of the three study sites is still suitable for Vaname cultivation. Nevertheless, it is important to accompany the cultivation process with additional input of water quality management technology.

Keywords: analysis; cultivation; feasibility; management; water quality; Vaname,

Penulis Korespondensi

Yuke Eliyani | yukeeliyani@yahoo.co.id 


\section{PENDAHULUAN}

Teluk Pangandaran merupakan wilayah pantai selatan Jawa yang memiliki potensi untuk budidaya udang vaname. Tiga lokasi yang merupakan sentra pengembangan udang Vaname di wllayah ini adalah Cimerak, Cijulang serta Cikangkung. Teknologi budidaya yang digunakan di lokasi ini mulai dari semi intensif sampai super intensif. Konsekuensi dari tingginya input produksi di antaranya adalah penggunaan pakan buatan dengan prosentase pemberian yang meningkat sejalan dengan tingkat tekhnologi budidaya yang diaplikasikan. Kondisi ini menstimulasi naiknya nilai nitrogen di media pemeliharaan udang, baik melalui sisa pakan buatan yang tidak dikonsumsi, buangan metabolit maupun sisa-sisa dekomposisi di dasar perairan. Peningkatan nilai nitrogen, dalam bentuk ammonia dan nitrit di perairan berkorelasi dengan perubahan parameter kuaitas air lainnya seperti nitrat, $\mathrm{pH}$, posfat, TSS serta DO, BOD. Dalam kisaran nilai tertentu, perubahan nilai nitogen tersebut menjadi hal yang perlu dicermati oleh para pembudidaya, karena hal ini menjadi salah satu tolak ukur kelayakan budidaya udang.

Peningkatan nitrit di lingkungan menyebabkan akumulasi nitrit dalam hemolimph, yang akan menyebabkan imunosupresif terhadap L. Vannamei, serta meningkatkan kerentanan terhadap infeksi Vibro alginolyticus (Tseng dan Chen 2004 dalam Barbieri et al., 2016). Peningkatan konsumsi oksigen dan ekskresi amonia pada juvenil udang vaname (Litopenaeus schmitti) yang terpapar peningkatan konsentrasi nitrit, menunjukkan bahwa nitrit bersaing dengan klorida untuk proses transfer pada saat melintasi membran eritrosit, sehingga pada oksidasi hemoglobin cenderung akan terbentuk methemoglobin. Hal ini menyebabkan terhambatnya tingkat pertumbuhan, kerentanan terhadap serangan penyakit, dan terjadinya mortalitas. Pada krustasea, tingginya nilai nitrit akan mengurangi toleransi termal dan menginduksi pembentukan methaemocyanin, sehingga menimbulkan hipoksia pada jaringan dan mengurangi efisiensi respirasi.

Mengingat Teluk Pangandaran merupakan salah satu lokasi pengembangan budidaya udang vaname dengan berbagai tingkatan teknologi, maka diperlukan berbagai kajian untuk melihat tingkat kelayakannya, salah satunya adalah dari segi kualitas air. Berkenaan dengan hal tersebut, penelitian ini bertujuan untuk mengetahui kelayakan teluk Pangandaran untuk budidaya Vaname (Litopenaeus vannamei) ditinjau dari sisi nilai parameter kualitas air. 


\section{BAHAN DAN METODE}

\section{Waktu dan Lokasi Penelitian}

Penelitian ini dilaksanakan pada bulan Juli tahun 2018 di wilayah pesisir Kabupaten Pangandaran Provinsi Jawa Barat. Analisis sampel kualitas air dilaksanakan di Laboratorium Balai Penelitian Pemulihan dan Konservasi Sumberdaya Ikan Jatiluhur.

\section{Populasi dan Sampel Penelitian}

Sampel yang digunakan adalah air yang diambil dari sumber untuk media pemeliharaan Udang vanname di 6 titik pengambilan, yang tersebar pada 3 kecamatan : stasiun 1 (ST 1) dan stasiun 2 (ST 2) berlokasi di Kecamatan Cijulang, stasiun 3 (ST 3) dan stasiun 4 (ST 4) berlokasi di Cimerak, serta stasiun 5 (ST 5) dan stasiun 6 (ST 6) berlokasi di Cikangkung.

\section{Rancangan Penelitian}

Penelitian ini merupakan penelitian eksplorasi dengan metode survei. Survei lapangan dilakukan langsung di wilayah budidaya yang menjadi lokasi penelitian.

\section{Alat dan Bahan Penelitian}

\section{Alat Penelitian}

Peralatan yang digunakan dalam penelitian ini adalah botol sampel, spektrofotometer, termometer, erlenmeyer, pipet volumetrik, pulp karet serta peralatan analisis kualitas air lainnya.

\section{Bahan Penelitian}

Bahan-bahan yang dipergunakan dalam penelitian ini antara lain: air sampel, reagen, serta bahan-bahan analisis kualitas air.

\section{Prosedur Penelitian}

Adapun langkah-langkah yang dilakukan pada saat penelitian:

\section{Tahap Pengambilan Sampel}

Pengambilan sampel dilakukan satu kali pada bulan Juli 2018. Sampel diambil langsung dari lokasi budidaya udang vaname di Kecamatan Cijulang, Cimerak serta Cikangkung Kabupaten Pangandaran Provinsi Jawa Barat. Sampel air selanjutnya dibawa ke Laboratorium Balai Penelitian Pemulihan dan Konservasi Sumberdaya Ikan Jatiluhur.

\section{Tahap Pemeriksaan Sampel} pH dan Suhu

Pengukuran suhu dilakukan dengan menggunakan termometer, sedangkan $\mathrm{pH}$ diukur dengan menggunakan $\mathrm{pH}$ meter merk Hanna.

Nitrit $\left(\mathrm{NO}_{2}{ }^{-}\right)$

Sebanyak $25 \mathrm{~mL}$ air sampel ditambah 5 tetes Sulfanilamide, dibiarkan 
selama 2 menit, kemudian ditambah 5 tetes NED. Akuades sebanyak $25 \mathrm{~mL}$ disiapkan sebagai blanko dan larutan standar sebanyak $25 \mathrm{~mL}$ yang sudah ditambahkan reagen-reagen seperti prosedur di atas. Air sampel, blanko, dan larutan standar dibiarkan selama 10 menit hingga menjadi berwarna pink yang stabil. Nilai absorbansinya kemudian diukur menggunakan spektrofotometer pada panjang gelombang $543 \mathrm{~nm}$. Konsentrasi nitrit dihitung dengan rumus :

$$
\mathrm{NO}_{2}\left(\mathrm{mg} \cdot \mathrm{L}^{-1}\right)=\frac{\mathrm{As}}{\mathrm{Ast}} \times \mathrm{Cst}
$$

Keterangan :

Cst $=$ konsentrasi larutan standar $\left(2 \mathrm{mg} \cdot \mathrm{L}^{-1}\right)$ Ast $=$ nilai absorbansi larutan standar As $=$ nilai absorbansi air sampel

\section{$\operatorname{Nitrat}\left(\mathrm{NO}_{3}{ }_{3}\right)$}

Sebanyak $5 \mathrm{~mL}$ air sampel ditambah $0,5 \mathrm{~mL}$ brucine dan $5 \mathrm{~mL}$ $\mathrm{H}_{2} \mathrm{SO}_{4}$ pekat di ruang asam. Disiapkan juga $5 \mathrm{~mL}$ akuades sebagai blanko dan 5 $\mathrm{mL}$ larutan standar, yang sudah ditambahkan reagen-reagen seperti prosedur di atas. Air sampel, blanko, dan larutan standar dibiarkan hingga dingin dan terbentuk warna kuning yang stabil. Absorbansinya kemudian diukur menggunakan spektrofotometer pada panjang gelombang $410 \mathrm{~nm}$. Konsentrasi nitrat dihitung dengan rumus :

$$
\mathrm{NO}_{3}\left(\mathrm{mg}_{\mathrm{L}} \mathrm{L}^{-1}\right)=\frac{\mathrm{As}}{\text { Ast }} \times \mathrm{Cst}
$$

Keterangan :
Cst $=$ konsentrasi larutan standar (2 mg. $\left.\mathrm{L}^{-1}\right)$

Ast $=$ nilai absorbansi larutan standar

As = nilai absorbansi air sampel

\section{Prosedur Pemeriksaan $\mathrm{PO}_{4}^{-}$}

Sebanyak $50 \mathrm{mLcontoh}$ uji duplo diambil dan masing-masing dimasukkan ke dalam erlenmeyer. Selanjutnya ditambahkan 1 tetes indikator fenolftalin ke dalam erlenmeyer. Jika terbentuk warna merah muda, tambahkan tetes demi tetes $\mathrm{H}_{2} \mathrm{SO}_{4}$. $5 \mathrm{~N}$ sampai warna merah mudah hilang Tahap berikutnya adalah tambahkan $8 \mathrm{~mL}$ larutan campuran dan dihomogenkan. Absorbansinya kemudian diukur menggunakan spektrofotometer pada panjang gelombang $810 \mathrm{~nm}$ selama 1030 menit. Nilai $\mathrm{PO}^{-4}$ dihitung menggunakan rumus

$$
\text { Kadar fosfat }\left(\mathrm{mg} P . \mathrm{L}^{-1}\right)=\mathrm{C} \times \mathrm{fp}
$$

Dengan pengertian :

C adalah kadar yang didapat dari hasil pengukuran $\left(\mathrm{mg} . \mathrm{L}^{-1}\right)$

$\mathrm{Fp}$ adalah faktor pengenceran

\section{Prossedur Pemeriksaan TSS}

Analisis sampel total suspended solid menggunakan metode gravimetri, di mana sampel yang diperoleh dianalisis dengan rumus :

$$
\operatorname{TSS}\left(\mathrm{mg} \cdot \mathrm{L}^{-1}\right)=\frac{(\mathrm{A}-\mathrm{B}) \times 1000}{\mathrm{~V}}
$$

TSS $=$ Total Suspended Solid $\mathrm{A}=$ berat kertas saring + residu kering $(\mathrm{mg})$ $B=$ berat kertas saring $(\mathrm{mg}) \mathrm{V}=$ volume contoh (L) 


\section{Prosedur Pengukuran BOD}

Langkah awal adalah melakukan pemeriksaan DO awal contoh, dengan menggunakan metoda Winkler. Setelah itu, dilakukan penyimpanan contoh selama 5 hari. Tahap berikutnya dilakukan lagi pemeriksaan DO dan dicatat sebagai $\mathrm{DO}_{5}$. Kemudian mg. $\mathrm{L}^{-1}$ $\mathrm{BOD}_{5}$ dihitung menggunakan rumus :

$$
\mathrm{BOD}\left(\mathrm{mg} \cdot \mathrm{L}^{-1}\right)=(\mathrm{D} 1-\mathrm{D} 2) / \mathrm{P}
$$

Dimana : D1 = DO awal, setelah sampling langsung diperiksa

D2 = DO setelah 5 hari disimpan di inkubator $\mathrm{P}=$ Pecahan desimal dari contoh yang digunakan, misalnya dilakukan 5 kali pengenceran.

\section{HASIL DAN PEMBAHASAN}

\section{Hasil}

Berikut disampaikan hasil analisis parameter kualitas air di lokasi penelitian pada Gambar1, 2, 3, 4, 5 dan 6. Hasil pengukuran menunjukan bahwa suhu
Teluk Pangandaran berkisar antara 24,0 sampai $24,5{ }^{\circ} \mathrm{C}$ pada keenam lokasi (ST1-ST6) selama waktu pengamatan (Gambar 1). Gambar 2 menunjukkan nilai $\mathrm{pH}$ perairan Teluk Pangandaran berkisar antara 7.62 hingga 7.90. Nilai ini masih tergolong air yang bersifat netral.

Gambar 3 menunjukkan nilai bahan endapan padat (TSS) pada keenam stasiun pengamatan di Teluk Pangandaran yaitu berkisar 22.6 hingga 60.4 mg.L-1. Gambar 4 menunjukkan parameter kimia pada perairan Teluk Pangandaran dari enam stasiun pengamatan dan perubahannya. Gambar tersebut menunjukkan nilai nitrit $\left(\mathrm{NO}_{2}\right)$ berkisar 0.004 hingga $0.006 \mathrm{mg.L}$ ${ }^{1}$, dan nitrat $\mathrm{NO}_{3}$ berkisar 0.176 hingga $0.269 \mathrm{mg} \cdot \mathrm{L}^{-1}$. Gambar 5 menunjukkan nilai $B O D$ dan oksigen terlarut pada

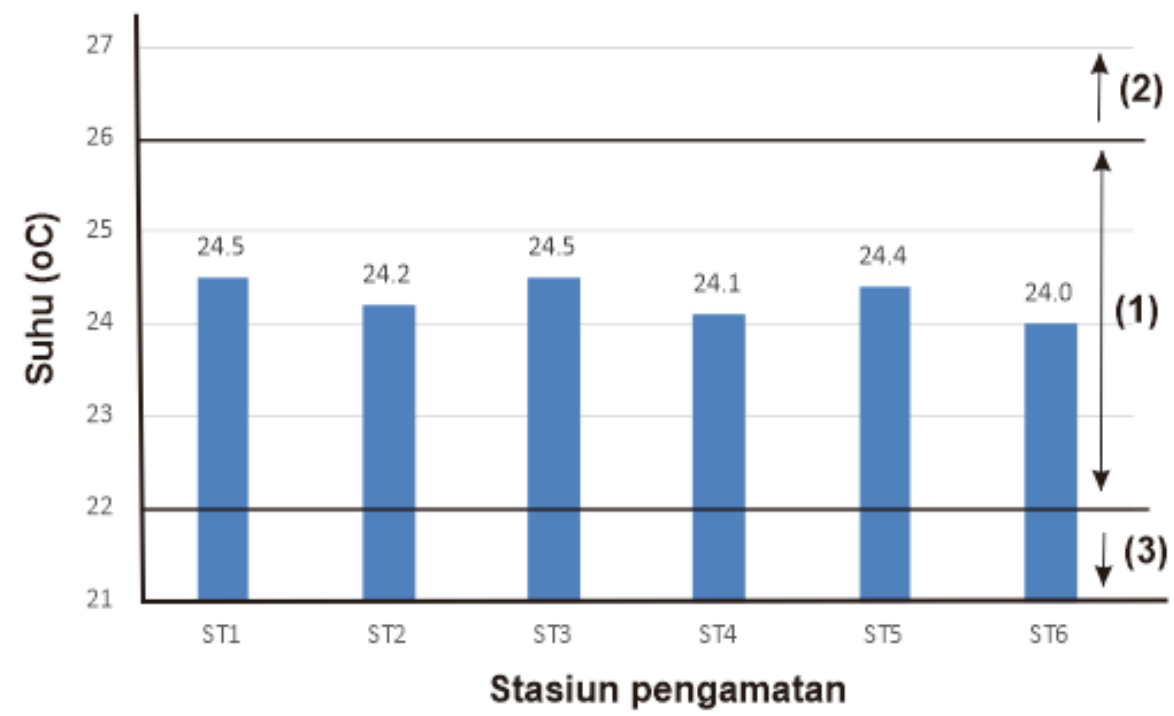

Gambar 1. Nilai suhu $\left({ }^{\circ} \mathrm{C}\right)$ pada pengamatan, (1) menunjukkan wilayah normal, (2) wilayah hyperthermia akut dan (3) wilayah hypothermia akut. 


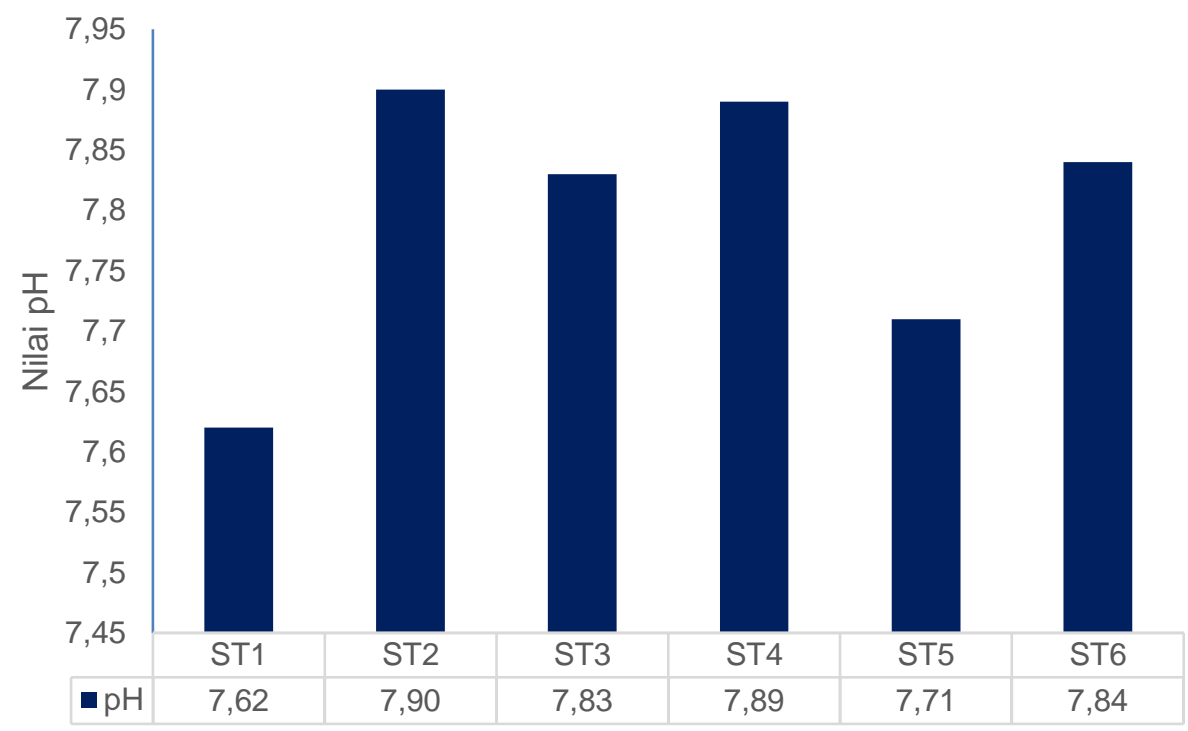

Gambar 2. Nilai $\mathrm{pH}$ pada berbagai stasiun pengamatan

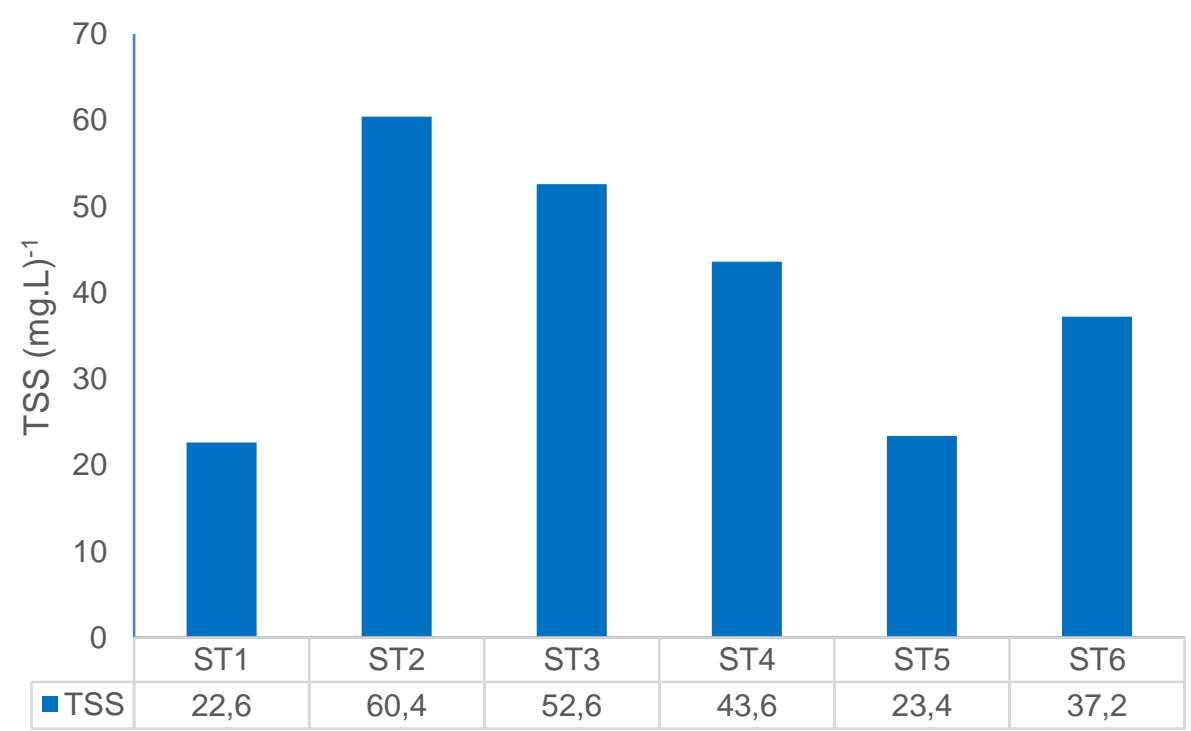

Gambar 3. Nilai TSS di lokasi penelitian

keenam stasiun pengamatan di Teluk Pangandaran. Nilai oksigen terlarut (DO) berkisar antara 4.1 hingga $6.6 \mathrm{mg} . \mathrm{L}^{-1}$. Nilai $\mathrm{BOD}_{5}$ berkisaur antara 0.01 hingga $0.98 \mathrm{mh} \cdot \mathrm{L}^{-1}$. Konsentrasi fosfat pada perairan Teluk Pangandaran dari enam stasiun pengamatan didapatkan nilai berkisar 0.0122 hingga $0.0415 \mathrm{mg} \cdot \mathrm{L}^{-1}$, seperti dilihat pada Gambar 6. Tingkat kepadatan fitoplankton dapat dilihat pada Tabel 1, dimana fitoplankton yang dominan adalah Asterionella sp. 


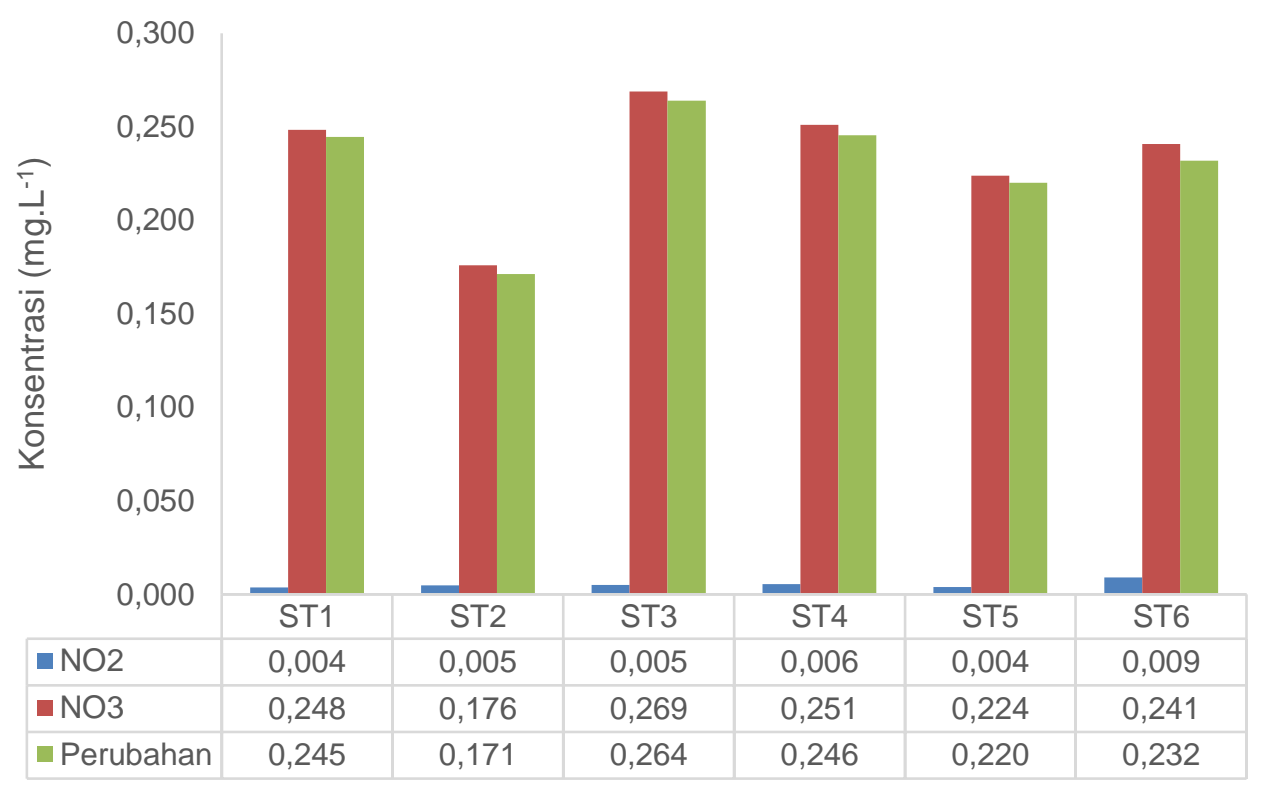

Gambar 4. Nilai nitrit dan perubahannya, serta nilai nitrat di lokasi penelitian

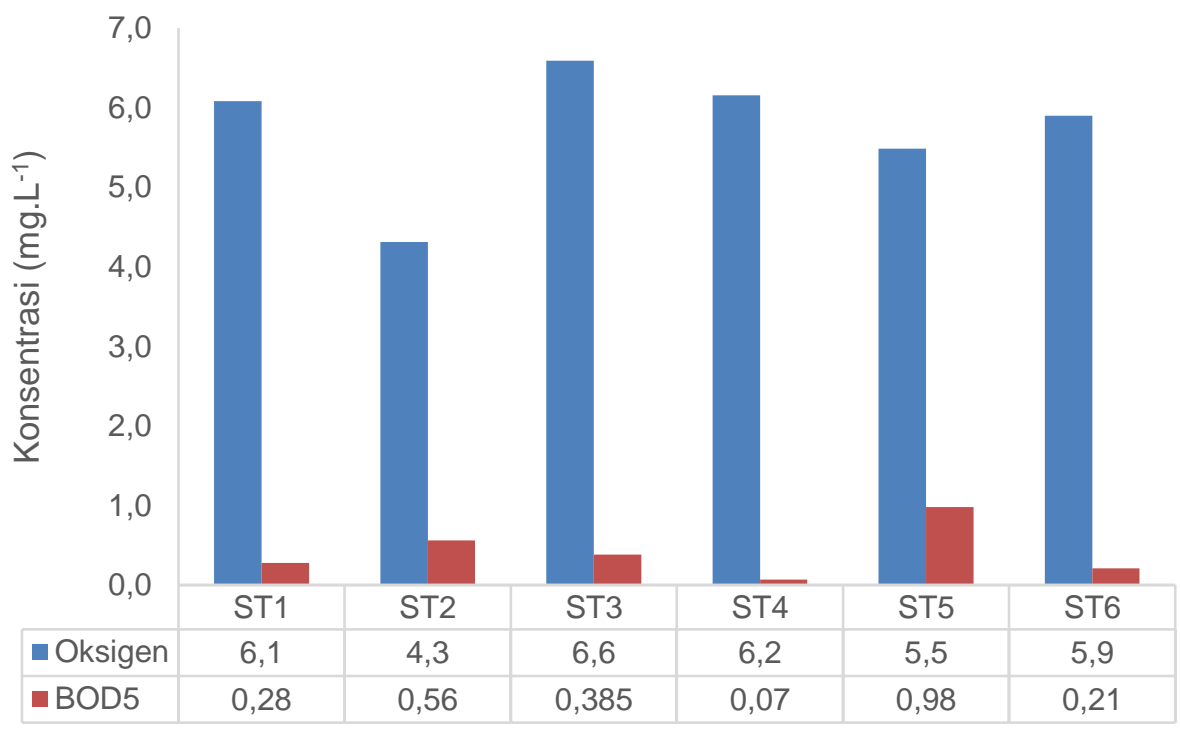

Gambar 5. Konsentrasi oksigen dan BOD di lokasi penelitian 


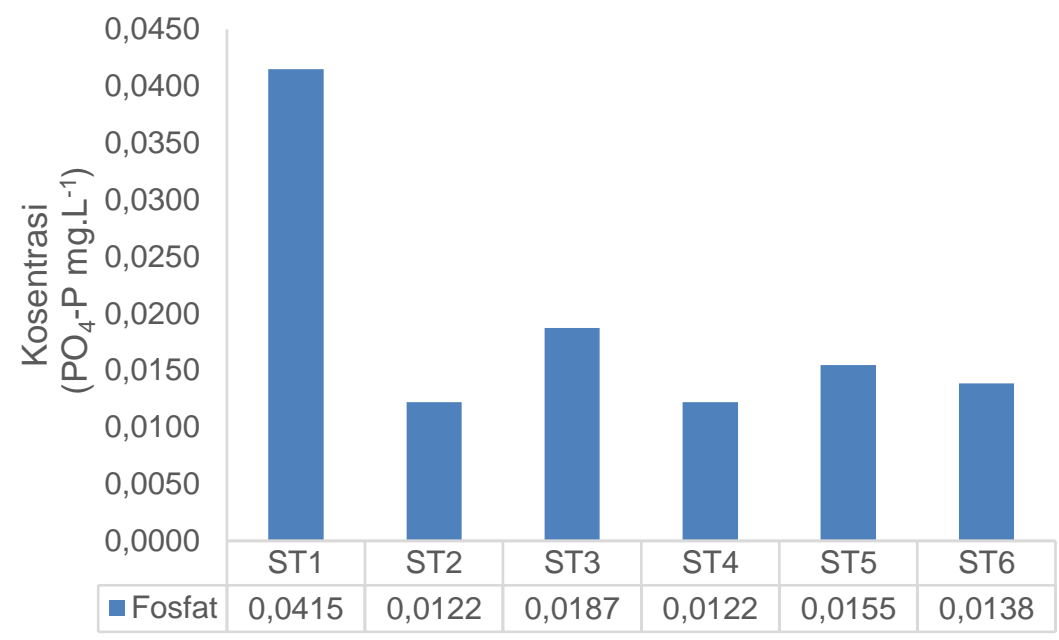

Gambar 6. Nilai fosfat $\left(\mathrm{PO}_{4}-\mathrm{P}\right)$ di lokasi penelitian

Tabel 1. Kepadatan fitoplankton di lokasi penelitian

\begin{tabular}{|c|c|c|c|c|c|c|}
\hline \multirow{2}{*}{$\begin{array}{l}\text { Fitoplankton } \\
\text { (sel/cacahan) }\end{array}$} & \multicolumn{6}{|c|}{ Stasiun } \\
\hline & ST1 & ST2 & ST3 & ST4 & ST5 & ST6 \\
\hline \multicolumn{7}{|l|}{ Chlorophyceae } \\
\hline Chlorella sp & & & & & 6 & \\
\hline \multicolumn{7}{|l|}{ Bacillariophyceae } \\
\hline Asterionella sp. & 4644 & 90 & & 300 & & \\
\hline Chaetoceros sp & 39 & & & 3 & 15 & \\
\hline Cococcneis sp & & & & & 3 & \\
\hline Coscinodiscus sp & & 15 & & & & 3 \\
\hline Flagillaria $s p$ & & & & & & 3 \\
\hline Minidiscus sp & & & & 3 & & \\
\hline Navicula sp & & & 9 & 3 & & \\
\hline Nitzchia sp & & & 3 & & & \\
\hline Rhizosolenia sp & & 15 & & 3 & & \\
\hline Synedra sp & & & & & 3 & 6 \\
\hline Triceratium sp & & & 3 & & & \\
\hline Jumlah total & 4683 & 120 & 15 & 312 & 21 & 12 \\
\hline
\end{tabular}

\section{Pembahasan}

\section{Hasil Pengukuran Suhu}

Suhu merupakan parameter fisika yang mempengaruhi metabolisme udang vaname. Hasil pengukuran menunjukan bahwa suhu yang terukur berkisar antara 24,0 sampai $24,5^{\circ} \mathrm{C}$ (Gambar 1 ). Fan, Wang, dan Wang (2019) menyatakan 
bahwa vaname adalah hewan tropis yang hidupnya sangat dipengaruhi oleh kondisi lingkungan, terutama suhu. Secara umum suhu tersebut mempengaruhi kelangsungan hidup dan pertumbuhan vaname. Lebih jauh dijelaskan bahwa perubahan suhu juga mempengaruhi keberadaan mikrobiota yang ada dalam tubuh, menyebabkan heat shock protein (HSPs) serta berubahnya struktur mukosa, sistem imun serta enzim metabolisme.

Menurut Xu et al. (2019) nilai suhu tersebut masih berada pada kisaran normal untuk kehidupan udang vaname yakni antara $22-26{ }^{\circ} \mathrm{C}$. Suhu di bawah 22 ${ }^{\circ} \mathrm{C}$ pada kondisi akut akan menyebabkan kondisi hypothermia sedangkan di atas $26{ }^{\circ} \mathrm{C}$ akan menyebabkan hyperthermia.

Kondisi hyperthermia dan hypothermia adalah kondisi yang pada tahap awalnya akan menyebabkan turunnya respon imun dari vaname sehingga udang akan mudah terserang penyakit yang disebabkan oleh virus maupun bakteri. Berdasarkan Gambar 1, kedua kondisi ini tidak terjadi di lokasi penelitian. Berdasarkan hasil pengukuran suhu perairan Teluk Pangandaran masih layak dijadikan lokasi budidaya udang vanamei.

\section{Hasil Pengukuran Nilai $\mathrm{pH}$}

Nilai $\mathrm{pH}$ merupakan parameter penting dalam kehidupan vaname.
Menurut Han et al., (2018) fluktuasi pH yang terjadi di tambak vanamei umumnya berkitar antara 6,6-10,2. Fluktuasi ini terutama disebabkan pada siang hari saat karbondioksida hasil respirasi udang, bakteri dan hewan lain dalam tambak diambil oleh fitoplankton untuk proses fotosintetis, sedangkan pada malam hari dapat dikatakan seluruh biota dalam tambak tersebut melepaskan karbondioksida. Alasan lain fluktuasi $\mathrm{pH}$ adalah terpaparnya sedimen dasar tambak akibat pergerakan udang, erosi tanah asam akibat hujan dan akumulasi bahan organik yang menyebabkan tambak menjadi lewat subur (eutrofikasi).

Hasil pengukuran $\mathrm{pH}$ ditampilkan pada Gambar 2. Dari gambar tersebut diketahui bahwa nilai $\mathrm{pH}$ yang terukur berkisar antara 7,62-7,90. Nilai ini merupakan nilai yang berada pada kisaran normal dalam mendukung kehidupan dan pertumbuhan udang. Menurut Duan et al. (2019) nilai $\mathrm{pH}$ optimal untuk pertumbuhan vanamei sekitar 8,3 sedangkan nilai $\mathrm{pH}$ di bawah 6,9 dan di atas 9,7 sudah akan menyebabkan stress. Lebih jauh dijelaskan bahwa ketika ikan sudah terpapar lebih dari 72 jam dalam kondisi stress $\mathrm{pH}$ ini maka yang terjadi adalah berubahnya morfologi dari usus, berubahnya aktivitas enzim pencernaan seperti amilase, lipase, tripsin yang ditandai dengan meningkatnya aktivitas 
enzim hexokinase (HK), pyruvate kinase (PK), cytochrome c oxidase (CCO), lactate dehydrogenase (LDH) dan kapasitas produksi oksigen. Sedangkan enzim yang berhubungan dengan kapasitas anti oksidan seperti enzim superoxide dismutase (SOD), glutathione S-transferase (GST) menurun aktivitasnya.

Enzim yang umumnya merupakan struktur asam amino atau protein banyak yang mengalami dampak akibat udang mengalami stress karena $\mathrm{pH}$. Oleh karena itu cara perlindungan yang dianggap masuk akal adalah dengan melakukan pemulihan (homeostasis) pada protein itu sendiri. Adapun prakteknya adalah dengan menyuntikan bahan heat shock protein (HSP) pada vaname. Aishi et al. (2019) telah melakukan hal tersebut pada pos larva udang vanamei. Hasilnya menunjukkan bahwa PL vanamei lebih terlindungi dari stress salinitas dan $\mathrm{pH}$ ketika disuntikan HSP70.

Hasil Pengukuran Total suspended solid (TSS)

TSS merupakan padatan yang tidak terlarut dalam air, yang dapat menyebabkan air keruh namun tidak langsung mengendap ke dasar perairan. Dengan demikian ukurannya lebih kecil dari sedimen dasar perairan tetapi lebih besar dari padatan terlarut atau yang biasa disebut total dissolved solid (TDS).
TSS adalah padatan yang tertahan di saringan ukuran 2 mikrometer dan padatan tersebut biasanya berupa lumpur, tanah liat, logam oksida, sulfida, ganggang, jamur dan bakteri.

Hasil pengukuran TSS selama penelitian ditampilkan pada Gambar 3. Dari gambar terlihat bahwa nilai TSS masih di bawah $80 \mathrm{mg} \cdot \mathrm{L}^{-1}$, artinya nilai TSS di lokasi pengambilan belum berdampak negatif terhadap vaname yang akan dipelihara.

Pada awalnya nilai TSS sebesar 500-600 mg. $\mathrm{L}^{-1}$ dikatakan akan berdampak negatif pada vaname namun penelitian lanjutan yang dilakukan Gaona et al. (2016) pada sistem Bioflock Technology (BFT) menunjukkan bahwa nilai TSS sampai sebesar $4000 \mathrm{mg} . \mathrm{L}^{-1}$ pun tidak berpengaruh negatif terhadap vanamei selama konsentrasi oksigen dijaga lebih dari $5 \mathrm{mg} \cdot \mathrm{L}^{-1}$.

Walaupun udang memiliki toleransi yang besar dalam beradaptasi dengan TSS, namun tetap saja akibat pemberian pakan yang terus menurus selama budidaya akan meningkatkan nilai TSS. Sampai pada titik tertentu peningkatan ini akan membahayakan kehidupan udang. Oleh karena itu peningkatan yang berlebihan harus dijaga agar tidak terjadi.

Zemor et al. (2019), melakukan penelitian tentang bagaimana menjaga peningkatan di atas dalam suatu sistem resirkulasi BFT. Hasilnya menunjukkan 
bahwa penggunaan clarifier mampu menjaga kestabilan nilai TSS untuk jangka waktu lebih lama. Semakin banyak clarifier yang digunakan maka semakin lama pula nilai TSS akan stabil. Sebagai perbandingan penggunaan 1 clarifier dengan 2 clarifier, menghasilkan nilai TSS yang lebih efisien (71,2 dan 47,9\%), air jauh lebih hemat (51,3 dan $50,7 \%)$ dan kotoran yang dibuang lebih sedikit (96 dan 97\%).

Dari kedua hasil penelitian di atas dapat disimpulkan bahwa nilai TSS selama penelitian, yakni antara 22,6-60,4 adalah kisaran nilai yang belum berdampak negatif pada vaname. Jika nantinya nilai TSS menjadi tinggi, maka dapat diatasi dengan menjaga nilai oksigen di atas $5 \mathrm{mg} \cdot \mathrm{L}^{-1}$ maupun dengan menggunakan clarifier.

\section{Pengukuran Nilai Nitrit dan Nitrat}

Nilai nitrit dan nitrat serta perubahannya selama penelitian ditampilkan dalam Gambar 4. Dari Gambar tersebut terlihat bahwa nilai nitrit dan nitrat berada dalam kisaran yang aman untuk budidaya vaname. Penelitian lain yang dilakukan ValenciaCastañeda et al. (2018), memperlihatkan bahwa nilai nitrit yang diperoleh selama penelitian masih berada pada kisaran yang aman untuk budidaya vanamei.

Nitrit dan nitrat merupakan dua bentuk nitrogen yang paling banyak ditemukan pada perairan yang digunakan untuk budidaya ikan atau udang. Sumber utama keduanya adalah dari pakan, berupa hasil ekskresi maupun berupa sisa pakan yang tidak dimakan. Bentuk pertama nitrogen yang terbentuk dari keduanya adalah amoniak. Selanjutnya bakteri heterotrof merubahnya menjadi bentuk nitrit, kemudian menjadi nitrat. Seluruh proses nitrifikasi dilakukan secara aerob dan bakteri yang dominan melakukannya adalah Nitrobacter dan Nitrosomonas.

Menurut Valencia-Castañeda et al. (2019) amoniak, nitrit dan nitrat memiliki daya racun yang berbeda terhadap vanamei. Daya racun dapat berbeda ketika amoniak, nitrit dan nitrat beridiri dan saat ketiganya menjadi suatu campuran. Hasil penelitian terhadap juvenil vanamei menunjukkan senyawa berdiri sendiri daya racun total amoniak nitrogen (TAN) pada LC50-96 jam adalah $29,0 \mathrm{mg} \cdot \mathrm{L}^{-1}$, nitrit sebesar 10,6 mg. $\mathrm{L}^{-1}$ dan nitrat $\left(\mathrm{NO}_{3}{ }^{-}-\mathrm{N}\right)$ sebesar $900 \mathrm{mg} \cdot \mathrm{L}^{-1}$. Sayangnya peneliti tidak menampilkan daya racun tersebut ketika sudah berbentuk campuran, mereka hanya menyatakan bahwa ketiganya saling berlawanan (antagonistic) dalam 24-72 jam dan mulai bertambah daya racunnya secara bersamaan mulai jam ke 72 sampai 96. Selanjutnya mereka pun menyatakan bahwa konsentrasi yang aman ketika daya racunnya sendiri 
sendiri untuk TAN, $\mathrm{NO}_{2}-\mathrm{N}$ dan $\mathrm{NO}_{3}-\mathrm{N}$ masing-masing 1,$45 ; 0,53$ dan 45,0 mg. $\mathrm{L}^{-1}$, sedangkan untuk campuran sebesar 0,48, 0,08 and 14,6 mg. $\mathrm{L}^{-1}$

Sebagai bahan yang beracun, di samping menyebabkan kerusakan sel darah merah dengan membentuk methemoglobin, nitrit juga menyebabkan kerusakan pada struktur usus, komposisi mikrobiota usus dan musin atau mukus yang terdapat dalam usus (Duan et al. 2018). Di samping itu, stress dengan nitrit pun ternyata menurunkan kapasitas antioksidan pada vaname (Wang et al. 2015).

Di samping nilai nitrit dan nitrat, Gambar 4 juga menampilkan data perubahan nitrit menjadi nitrat sebagai akibat dari proses nitrifikasi yang terjadi. Dari data terlihat bahwa perubahan yang terjadi cukup besar. Hal ini mengindikasikan oksigen sebagai salah satu kebutuhan utama dalam proses ini pasti jumlahnya cukup.

\section{Oksigen dan BOD5}

Oksigen adalah unsur yang sangat dibutuhkan oleh untuk proses kimia (oksidasi) dan biokimia (respirasi) yang terjadi di perairan. Nilai oksigen dan BOD5 selama penelitian ditampilkan pada Gambar 5.

Walaupun kadar oksigen terendah yang disarankan untuk udang vaname adalah $4 \mathrm{mg} \cdot \mathrm{L}^{-1}$, namun secara umum udang ini masih dapat tumbuh dengan cukup baik pada kadar oksigen $3 \mathrm{mg} \cdot \mathrm{L}^{-1}$. Karena udang ini dipelihara dengan kepadatan sangat tinggi (sekitar 200 ekor. $\mathrm{m}^{-2}$ ) oksigen menjadi salah satu parameter yang mendapat perhatian besar dari para peneliti udang vanamei. Kepadatan ini tentunya dapat menurunkan kandungan oksigen dalam air dan menyebabkan berkembangnya bakteri-bakteri pagogenik dalam air.

Walaupun cara konvensional untuk menambah oksigen terus dilakukan menggunakan aerasi, penelitian lain yang saat ini terus berlangsung adalah pengembangan atau pemberian reactive oxygen species (ROS). ROS adalah molekul-molekul yang mudah bereaksi dan dalam reaksinya menghasilkan oksigen. Molekul yang dimaksud antara lain peroksida, radikal hidroksil, superoksida dan single oxide.

$\mathrm{He}$ et al. (2017) menyatakan bahwa pemberian ROS mampu meningkatkan ketahanan vaname terhadap penyakit white spot syndrome virus (WSSV) dan Vibrio alginolyticus. Salah satu bahan yang digunakan untuk meningkatkan ROS pada vanamei adalah $L$. vannamei reactive oxygen species modulator 1 (LvROMO1). Meski belum menggunakan ROS, kondisi oksigen di lokasi penelitian cukup tinggi bahkan sangat mendukung kehidupan vaname. Di samping itu, tingginya nilai 
oksigen menjadi salah satu penyebab mengapa konversi nitrit menjadi nitrat cukup tinggi.

Dilihat dari nilai BOD5 selama penelitian, terlihat bahwa nilai tersebut sangat kecil yakni antara 0,21 - 0,98 mg. $\mathrm{L}^{-1}$. Nilai ini sangat jauh di bawah kriteria baku mutu biota laut yakni sebesar 20 mg.L-1 (Keputusan Menteri Negara Lingkungan Hidup Nomor 51 Tahun 2004 dan Keputusan Menteri Negara Kependudukan dan Lingkungan Hidup Nomor 2 Tahun 1988 tentang Baku Mutu Air Laut untuk Biota Laut). Dari nilai BOD5 pun dapat disimpulkan bahwa perairan sekitar lokasi penelitian (Teluk Pangandaran) bukan perairan yang tercemar dan apabila hanya berdasarkan nilai oksigen dan BOD5 perairan ini layak untuk budidaya vaname.

\section{Hasil Pengukuran Fosfat dan Plankton}

Berdasarkan pengukuran fosfat yang dilakukan selama penelitian, terlihat nilai fosfat di perairan berkisar antara 0,0122 - 0,0415 mg. $\mathrm{L}^{-1}$. Nilai tersebut menunjukkan bahwa kondisi perairan di lokasi penelitian adalah perairan yang cukup subur sehingga merupakan perairan yang layak digunakan untuk budidaya. Adapun nilai tersebut untuk masing-masing stasiun ditampilkan dalam Gambar 6.
Posisi fosfat sebagai parameter kunci dalam menentukan tingkat kesuburan perairan, terlihat dari kepadatan fitoplankton di lokasi penelitian sebagaimana ditampilkan dalam Tabel 1. Nilai fosfat terbesar terjadi di Stasiun 1 (ST1) sebesar $0,0415 \mathrm{mg} \cdot \mathrm{L}^{-1}$, dan ternyata fitoplankton terpadat pun berada di lokasi ST1. Dengan demikian dalam kasus ini keberadaan fosfat menentukan tingkat kepadatan fitoplankton di perairan ini.

\section{SIMPULAN DAN SARAN}

Hasil analisis kualitas air untuk parameter suhu, $\mathrm{pH}, \mathrm{TSS}, \mathrm{NO}_{2}, \mathrm{NO}_{3}$, $\mathrm{DO}, \mathrm{BOD}_{5}$, serta $\mathrm{PO}_{4}-\mathrm{P}$ masing - masing sebesar 24-24,5 ${ }^{\circ} \mathrm{C} ; 7,62$ - 7,90 ppm; 0,004 - 0,009 ppm; 0,176 - 0,269 ppm; 4,3 - 6,6 ppm; 0,070 - 0,980 ppm; $0,0122-0,00415$ ppm. Bedasarkan nilainilai parameter ini, dari segi kualitas air ketiga lokasi penelitian masih layak untuk budidaya Vaname, namun harus disertai dengan adanya tambahan input teknologi pengelolaan kualitas air.

\section{DAFTAR PUSTAKA}

Aishi, Kou, Saranya Sinnasamy, Thomas H. MacRae, Tengku Sifzizul Tengku Muhammad, Aijun Lv, Jinfeng Sun, Shuaijun Chen, Hongyue Shi, Tan Min Pau, Muhd Danish-Daniel Abdullah, dan Yeong Yik Sung. 2019. "Hsp70 knockdown reduced 
the tolerance of Litopenaeus vannamei post larvae to low $\mathrm{pH}$ and salinity." Aquaculture 512:734346.

Barbieri, Edison, Ana Cristina Vigliar Bondioli, Camila Batista de Melo, dan Marcelo Barbosa Henriques. 2016. "Nitrite toxicity to Litopenaeus schmitti (Burkenroad, 1936, Crustacea) at different salinity levels." Aquaculture Research 47(4):1260-68.

Duan, Yafei, Qingsong Liu, Yun Wang, Jiasong Zhang, dan Dalin Xiong. 2018. "Impairment of the intestine barrier function in Litopenaeus vannamei exposed to ammonia and nitrite stress." Fish \& Shellfish Immunology 78:279-88.

Duan, Yafei, Yun Wang, Qingsong Liu, Jiasong Zhang, dan Dalin Xiong. 2019. "Changes in the intestine barrier function of Litopenaeus vannamei in response to $\mathrm{pH}$ stress."

Fish \& Shellfish Immunology 88:142-49.

Fan, Lanfen, Lei Wang, dan Zhenlu Wang. 2019. "Proteomic characterization of the hepatopancreas in the Pacific white shrimp Litopenaeus vannamei under cold stress: Revealing the organism homeostasis mechanism." Fish \& Shellfish Immunology 92:438-49.
Gaona, Carlos Augusto Prata, Fabiane da Paz Serra, Plínio Schmidt Furtado, Luis Henrique Poersch, dan Wilson Wasielesky. 2016. "Effect of different total suspended solids concentrations on the growth performance of Litopenaeus vannamei in a BFT system." Aquacultural Engineering 7273:65-69.

Han, Si-yin, Bao-jie Wang, Mei Liu, Meng-qiang Wang, Ke-yong Jiang, Xin-wei Liu, dan Lei Wang. 2018. "Adaptation of the white shrimp Litopenaeus vannamei to gradual changes to a low-pH environment." Ecotoxicology and Environmental Safety 149:203-10.

He, Hong-Hui, Yi-Miao Chi, Kai Yuan, Xiao-Yun Li, Shao-Ping Weng, JianGuo He, dan Yi-Hong Chen. 2017. "Functional characterization of a reactive oxygen species modulator 1 gene in Litopenaeus vannamei." Fish \& Shellfish Immunology 70:270-79.

Valencia-Castañeda, Gladys, Martín G. Frías-Espericueta, Ruth C. Vanegas-Pérez, María C. ChávezSánchez, dan Federico PáezOsuna. 2019. "Toxicity of ammonia, nitrite and nitrate to Litopenaeus vannamei juveniles in low-salinity water in single and ternary exposure experiments and their 
environmental implications."

Environmental Toxicology and Pharmacology 70:103193.

Valencia-Castañeda, Gladys, Ruth C. Vanegas-Pérez, Martín G. FríasEspericueta, María C. ChávezSánchez, Javier Ramírez-Rochín, dan Federico Páez-Osuna. 2018. "Comparison of four treatments to evaluate acute toxicity of nitrite in shrimp Litopenaeus vannamei postlarvae: Influence of feeding and the renewal water." Aquaculture 491:375-80.

Wang, Yun, Zheng Li, Jian Li, Ya-Fei Duan, Jin Niu, Jun Wang, Zhong Huang, dan Hei-Zhao Lin. 2015. "Effects of dietary chlorogenic acid on growth performance, antioxidant capacity of white shrimp Litopenaeus vannamei under normal condition and combined stress of low-salinity and nitrite." Fish \& Shellfish Immunology 43(2):337-45.

Xu, Zihan, Weiliang Guan, Dandan Xie, Wenjing Lu, Xingchen Ren, Jiajia Yuan, dan Linchun Mao. 2019. "Evaluation of immunological response in shrimp Penaeus vannamei submitted to low temperature and air exposure." Developmental \& Comparative Immunology 100:103413.

Zemor, J. C., W. Wasielesky, G. K. Fóes, dan L. H. Poersch. 2019. "The use of clarifiers to remove and control the total suspended solids in largescale ponds for production of Litopenaeus vannamei in a biofloc system." Aquacultural Engineering 85:74-79. 